\title{
Transfer of Development Rights as Incentives for Regeneration of Illegal Settlements
}

\author{
Nico Calavita ${ }^{1, a}$, Francesco Calabrò ${ }^{2, b}$, Lucia Della Spina ${ }^{2, c}$ \\ ${ }^{1}$ San Diego State University, Campanile Drive, San Diego, California (USA) \\ ${ }^{2}$ Mediterranea University of Reggio Calabria. PAU - Department of Heritage, Architecture, Urban \\ Planning, Via Salita Melissari - 89124, Reggio di Calabria, Italy \\ ancalavit@mail.sdsu.edu, ${ }^{b}$ francesco.calabro@unirc.it, ${ }^{c}$ lucia.dellaspina@unirc.it
}

Keywords: Transfer of Development Rights, Illegal Settlements, Urban Regeneration.

\begin{abstract}
Southern Italian cities are often characterized by widespread phenomena of illegal settlements, that have resulted - among other things - in a worsening of the quality of life in the urban-rural interface, and the weakening of the considerable architectural interest of the entire city. The goal of this paper is to propose an approach that would help rehabilitate what is already built, and in so doing improving on the quality and liveability of those cities.

This approach is based on a particular methodology based on the promotion of Urban Complex Programs (PUC), which provide a system of development rights resulting from the demolition of unfinished illegal settlements.

The benefits of this approach are many, including improvements in efficiencies and safety, meeting demands of environmental protection and reducing consumption of energy, seismic risk prevention and improving the liveability and attractiveness of the areas with illegal settlements.

These benefits can be obtained only on one condition: that they are based on a system of collective and public amenities in accordance with the principle of sustainability in multiple dimensions (environmental, cultural, technological, political, institutional, social and economic). But for this approach to be viable it needs also to be convenient for the private actors as well.

With this paper we hope to provide first an original approach that can improve the conditions of cities burdened with the problems of illegal settlements that is both sustainable and convenient and, second, an instrument that can provide information for both the public and private sectors on the fairness of the procedure and their mutual interest in pursuing this approach.
\end{abstract}

\section{Introduction}

One of the most significant indicators of the competitiveness of a territory is its capacity to attract people and capital. The aesthetic factor, the beauty of a city is, according to the 47nd Annual Report CENSIS [1] on the social situation of Italy, one of the most important aspects of urban quality perceived by the public and a factor considered when choosing a place in which to live or invest. Additional factors that call for the rehabilitation of urban environmental systems are the movement to combat climate change and the European Landscape Convention that has called for the recovery of degraded landscapes.

Moreover, that in urban policies should give priority to the regeneration and urban requalification in respect to the expansion is a fact absolutely sure, so much in the cultural debate, as in the political sphere. Especially if we reason in terms of efficient use of territorial resources, it is clear that it makes no sense to consume other urban ground, thus expanding the already urbanized land, when in the same time, within the city, there are forms of degradation that dilate ever more with the expansion of the city. The degraded areas (disused or unqualified) in the urban system, unanimously are considered to be important resources for the future of the city: through their redevelopment and reconversion it is possible insert in the urban fabric functions of strategic importance, for the promotion of economic and social development, capable of enhancing the competitiveness of the city. 
However, the urban regeneration as well as being hindered by complex and varied situations (related to the property, countered by long and urbanization procedures, from multiple authorization devices, high costs of remediation and demolition, and in any case by the more difficulties in organizing the work that are reflected in higher costs compared to building in areas of expansion), in many cases, it is considered a "market failure" in the sense that the market, through their own efforts, is unable to achieve it [2].

Reggio Calabria is a city characterized by a significant number of buildings built in contrast with the provisions of planning instruments. Most of these buildings were legalized under various laws that have occurred since the Law n. 47 of 1985. Some of these buildings, however, were never completed. Many of them are just building shells, and the rest are in various states of completion. The considerable diffusion of these unfinished buildings in virtually all areas of the city contributes to a deterioration of the quality of urban life.

It is therefore necessary that there is a public intervention that creates favorable conditions for private investment.

The experience of the PUC (innovative programs in urban areas of ministerial initiative) implied precisely this awareness. But these experimentations were practically complete, as well as the financial flows that they had conveyed in our cities.

Several studies have attempted to address the issue of the regeneration of illegal settlements, but little attention has been paid to the system of economic advantages and disadvantages that affect the viability of these buildings.

In the absence of financial and fiscal incentives, the feasibility of the activities of urban requalification is entrusted to the evaluation of public and private benefits and to the creation of more favorable economic conditions for such initiatives.

In the next section we present the concept of the Transfer of Development Rights that we are proposing as a tool to address this issue, followed by a section on the main methodological aspects of an approach to the regeneration of illegal settlements based on the exchange of development rights, in accordance with the principles of sustainability.

\section{Creating and transferring Development Rights}

In conditions of fragmentation and decay in urbanized areas, the Transfer of Development Rights (TDR) model could work for the regeneration of sprawling and/or illegal settlements, degraded areas and inactive industrial complexes.

The objectives of TDR programs can be very different and they starts from the preservation of undeveloped land and the limitation of urban sprawl, to the protection of cultural heritage and the safeguarding of ecologically sensitive area such as wetlands or coastal zones. It is a technique that has been around for many decades. It was first proposed by Costonis in 1973 and has been attempted in various contexts in the US with some degree of success [3].

It is based on the assumption that all property owners have some (however small) right to development and that this right can be severed from all the other rights associated with land ownership, and transferred to other properties.

Such a program would include the definition of "sending areas", areas that the public entity wants to protect from development, and "receiving areas," areas where densities can be increased through the acquisition of development rights on the part of developers from the sending areas.

Probably the most effective way to implement TDR is to establish a development rights bank where those rights can be bought and sold. Of course, for a TDR system to function, a strong demand for additional development right is necessary, strong enough for developers to calculate that there is enough demand for their product to warrant the acquisition of additional development rights $[4,5]$.

As the extensive literature on TDRs indicates, there are several potentialities about this technique, especially if compared to the rigid traditional planning tools. TDRs are also an instrument for greater planning equity because they allow for the fair redistribution of the values and disvalues produced through planning. They are more efficient than zoning (thanks to the use of 
the market's levers), they lessen the interest of owners for the outcome of planning decisions, and, finally, they allow for the compensation of owners penalized by urban planning's decisions.

We should mention that in the receiving areas, jurisdictions are likely to assign, on the basis of the Master Plan, different potential densities above the base density, depending on the characteristics of the area. In some cases, it is possible that the same density will be assigned to the entirety of a receiving area. We feel that the single index is probably the most appropriate under the circumstances in Reggio Calabria, from an ethical and practical point of view.

As mentioned above, southern cities in Italy are often characterized by phenomena of diffuse illegality that have ended up suffocating settlements of considerable architectural interest thus diminishing their overall attractiveness.

The city of Reggio Calabria in particular is characterized by a significant presence of buildings built against the regulations of the plan for the city. Most of them have been legalized on the basis of several laws (called "Leggi di Condono" in Italian), but their legalization has not led, in many cases, to their completion.

Their status varies, with some of them being just a shell, others with the interior completed, but without an adequate façade. These buildings are practically in all areas of city, reducing the urban quality of the entire urban ensemble.

Several studies, have tried to confront the theme of requalification of illegal settlements. While addressing the difficulties posed by the normative framework, these studies have not addressed adequately the issue of the system of economic benefits and liabilities, which could help solve this intractable problem.

\section{The urban system in metropolitan areas and the new building production}

Urban Sprawl, i.e. low density and leap-frogging development, is one of the negative indicators/markers of the expansion at the fringes of metropolitan areas [6]. These low densities that characterize the expansion zones of the greater urban areas create significant problems:

- Require significant investments in public infrastructures;

- Make inefficient the services of public transport;

- Produce damaging effects in the hydrogeological territorial asset because of the progressive waterproofing of the land;

- Consume vast amounts of open space, in some cases prime agricultural land

The Preliminary Document of the "Piano Strutturale Comunale (PSC)" of Reggio Calabria [7] underlines the excessive size of housing rather than the real needs of the town including a decline in areas destined to public services. Such a decline is significant especially when referred to the standards of D.M. 1444/1968, a national law that established minimum standards for public facilities, such as day-care centers, parks and libraries. This lack of existing public facilities and inadequate standards for expansion areas makes it difficult the designation of new areas for new building expansion. Together with the collapse of demand, public and private, linked to the negative trend of the economic cycle, this has caused the substantial paralysis of the building sector, with dramatic effects on the local economy and a decline in the employment rate.

\section{A strategy for energizing the building sector}

The dilemma concerning the acquisition of the standards area to endow the town of necessaries services is of different solution in the short term, because of the lack of public resources to meet the existing deficit. In addition, there are other needs that require attention:

- the crisis of the building sector, and its effects on employment.

- the progressive obsolescence of the real estate stock because of the higher standards, both quantitative and qualitative (energy performance, innovative technologies, etc.);

- the problems of the illegal settlements;

These needs must be satisfied but, within the system of public and collective goals and on the basis of sustainability's principles we must also consider the following objectives: 
- the preservation of agricultural soil;

- no additional development;

- no monetary cost for the collectivity;

- optimization of the use of the infrastructures and services.

The achievement of these objectives is possible through several strategies.

\section{The system of public and private conveniences}

The unfinished illegal buildings are a liability for the collectivity and also for the owners. When inhabited, because of their unfinished conditions the buildings have poor energy performances and decay rapidly, even structurally, because of their exposure to the atmospheric agents.

Our proposal is to provide the promotion of PUC Urban Complex Programs, focused on a system of assigning development rights as a reward deriving from the demolition of illegal, unfinished buildings. The owner of the building could then sell those rights to be utilized in appropriate areas of the city.

The so-called "Integrated Programs" or "Programs Urban Complex" (PUC) were born in the 90s (Law $n^{\circ} 179 / 92$ ) as an innovative mode of action for the redevelopment of the city and, more generally, for the governance of urban and territorial transformations, in a time of scarcity of public resources for the management of urban transformations and limits of practicality of the General Plan ("PRG: Piano Regolatore Generale" in Italian) [8].

The PUC, implementation tools in derogation from the PRG act on three common problems:

1. the complexity of urban transformation (of the functions, of the competences, of the process, of the interests involved, of the management). Overcoming, then the monofunctionality, such as for example Recovery Plans (Law ${ }^{\circ}$ 457/1978);

2. the necessity for integration (between public and private actors, between ends and means, between the different sector policies, party interests, etc.).

3. the character "strategic", with a limited number of priority targets shared by the productive forces and social, achievables a time period determined and well correlated with the necessary conditions of administrative feasibility, financial and technical.

Therefore, the valuation ("estimativa" in Italian) question proposed is framed, in the context of PUC, by the determination of building rights's quantity to be paid in return of the demolition of cubic meters of illegal volume not completed. In addition, the valuation process imposes the determination of a plurality of values [9]. The total market value to be assigned would be based on calculating the value of the buildings that were legalized, but remain unfinished, if they were to be completed. In addition, the total market value should include the cost for their demolition, including the costs for waste disposal.

\section{The basic assumptions for the construction of the experimental model}

The hypothesized model, of an experimental character, is introduced as a tool for overcoming the difficulties presented above. It provides the concession of building rights to owners of illegal buildings that have been legalized but not finished, in return of the demolition of their building. The building rights that had been acquired through the legalization of their structure can now be transferred for the realization of new buildings in the ambit of urban regeneration's programs.

The appraisal model proposed is derived by a model already developed by the authors for the estimation of extraordinary charges from private entities in the ambit of PUC $[10,11,12]$.

\section{Used procedure for the quantification of development rights}

The process is divided into five phases:

Step 1 - Identification of the property to be demolished.

Step 2 - Appraisal of the value to be indemnified.

Step 3 - Identification of the land area of development rights. 
Step 4 - Appraisal of the unitary value of development rights.

Step 5 - Quantification of development rights to be granted as compensation.

Variables to be determined are composed of:

$\mathrm{Vi}=$ value to be indemnified

$\mathrm{Vd}=$ total market value of development rights.

$\mathrm{Vd}^{\prime}=$ unitary; value of market development rights.

$\mathrm{Qd}=$ quantity of development rights to be granted for one cubic meter of demolished volume.

$\mathrm{Vm}^{\prime}=$ current market value of the properties to be demolished.

$\mathrm{Vc}^{\prime}=$ Value of the cost of demolition burden including garbage disposal.

$\mathrm{I}=$ Incentive to the property owner for the demolition.

In order to verify the economic feasibility of the procedure, it must result:

$\mathrm{Vi}=\mathrm{Vm}^{\prime}+\mathrm{Vc}^{\prime}+\mathrm{I}$

Considering the unitary value of market development rights, we get:

$\mathrm{Vd}=\mathrm{Vd}$ ' $\mathrm{x} \mathrm{Qd}$

but since:

$\mathrm{Vd}=\mathrm{Vi}$

substituting in (1) we get:

$V d^{\prime} x \mathrm{Qd}=\mathrm{Vm} \mathrm{m}^{\prime}+\mathrm{Vc}+\mathrm{I}$

From which:

$\mathrm{Qd}=\left(\mathrm{Vm}^{\prime}+\mathrm{Vc}+\mathrm{I}\right) / \mathrm{Vd}$

Appraisal of current market value of real estate to be demolished

Being buildings susceptible to transformations, the most appropriate criterion to appraise the market value of the buildings to be demolished is undoubtedly the value of transformation.

Taking into account the high costs of structural adjustment and the completion of the buildings, using this criterion, the synthetic appraisals performed lead to negative values, that is the costs for the adjustment and the completion of the buildings are superior than the market value of completed buildings: it is the demonstration of the lack of convenience for the private owner to take action on their building.

\section{Appraisal of value of the cost of demolition and waste disposal}

Given the purposes of a programmatic nature for which the estimated value will be used, it is appropriate to proceed to a synthetic or parametric appraisal.

In the absence of more reliable information, it is necessary to resort to available sources [13]. These data were then validated by means of a comparison with some stakeholders: in particular, the comparison has taken place with the National Builders Association of Reggio Calabria "Associazione Nazionale Costruttori Edili (ANCE)" and with consultants in the field. 


\section{Appraisal of unitary market value of development rights}

With respect to the appraisal question under examination, it's necessary to focus attention on one of the factors that contribute to determine the cost of production, that is, the market value of the land. calculated as the rent of land resulting from the assigned development rights.

In effect it is possible to affirm that the market value of land is a function of several intrinsic and extrinsic factors (location, morphology, etc..), that are of particular importance for its building capacity.

It's possible to affirm therefore that, given two parcels of land, A and B, with identical characteristics except for building capacity, the difference between their market values corresponds to the total market value of development rights:

$\mathrm{Vd}=\mathrm{Vm} \mathrm{A}-\mathrm{VmB}$

So the unitary value Vd' of development rights is obtainable as the ratio between the total market value of the building capacity $\mathrm{Ce}$

$\mathrm{Vd}^{\prime}=\mathrm{Vd} / \mathrm{Ce}$

\section{Appraisal of development rights to grant}

The amount of building rights to be granted, as mentioned before, must be capable to generate a profit for the owner of the building to be demolished; such a profit is the one that makes the operation economically feasible.

Realfonzo, taking up the work of Forte de 'Rossi [14], believes that the profit for the developer oscillates between $10 \%$ of $30 \%$ of the market value, which increases with the increase of the market value VM and the entity of the profit will depend on the general economic conditions and the qualitative characteristics of the product [15].

Public Works norms, that estimate estimated unitary prices of construction works, indicates $10 \%$ as ordinary profit margin in the construction industry $[16,17]$.

This percentage may be considered adequate in the first hypothesis, within a logic aimed to maximize the public benefits, so you will have:

$\mathrm{I}=10 \%\left(\mathrm{Vm}^{\prime}+\mathrm{Vc} \mathrm{c}^{\prime}\right)$

\section{Conclusions. Public, private conveniences and sustainability of the processes}

The above calculations illustrate what would be the convenience of owners to proceed at demolition.

Why should the public administration proceed in this way? What benefits derive to the collectivity? Possible benefits include the decrease of the real estate's stock and the preservation of the land on which the illegal buildings were located. The decrease of the total real estate's stock in the city would result from a decrease in allowable densities, i.e., the development rights would be less than the existing legalized.

Regarding the consumption of soil, it should be underlined that the building rights would be used in the ambit of urban regeneration programs relatives to areas already urbanized, orienting the investments of the real estate's sector toward those areas, avoiding therefore the expansion of the urbanized zones at expense of open space. The described evaluation procedure is characterized by a remarkable ease of use, giving to the Public Administrations an approach that meets requirements of transparency and equity toward the collectivity, thus obviating a grave lack of current experiences in urban planning's processes.

The illustrated methodology still has an experimental character and it is susceptible, therefore, of further developments and refinements in the light of future insights and desirable disciplinary 
comparisons. In a logic finalized to maximize the public benefits, it will be necessary first of all to verify the reliability of the lower thresholds of the subsidies, below which private owners haven't sufficient motivations to participate: this threshold will be the level of subsidies to be utilized in the ambit of the model's application. Future research, will be oriented to make stronger the reliability of estimation model. In particular the questions linked to the variations in the value of development rights will be related to the characteristics of the receiving areas that are linked to the actuation of the PUCs.

Other issues to be explored include:

- verification of the market activity level necessary to make work the model;

- legal profiles related to the land use law.

\section{Acknowledgments}

The paper is the result of the joint work of the three authors. However, Nico Calavita is responsible for the "Introduction", Francesco Calabrò is responsible for "The urban system in metropolitan areas and the new building production " paragraph, Lucia Della Spina is responsible for "Creating and transferring Development Rights" paragraph. The paragraphs: "The system of public and private conveniences" is the result of the joint work of the two authors: Francesco Calabrò and Lucia Della Spina.

\section{References}

[1] Censis: $47^{\circ}$ Rapporto annuale sulla situazione sociale del Paese, Milano, Franco Angeli, (2013)

[2] S. Stanghellini: Incentivare la rigenerazione urbana contrastando il consumo del suolo. In: Dossier su rendite ed economia urban. Information on http://www.italianieuropei.it/it/ leiniziative/convegni/item/download/48.html. (2012)

[3] J. Costonis: Development Rights Transfer: An Exploratory Essay, 83 Yale Law Jornal 75, 85, (1973)

[4] R. Camagni: Il finanziamento della città pubblica: la cattura dei plusvalori fondiari e il modello perequativo, in F. Curti, Urbanistica e fiscalità locale, Maggioli, Rimini (1999)

[5] F. Chiodelli, S. Moroni: Indice unico e trasferibilità indifferenziata dei diritti edificatori. In: AISRe Associazione Italiana di Scienze Regionali, XXXII Conferenza Scientifica Annuale, Torino, 15-17 Settembre 2011, Il ruolo delle città nell'economia della conoscenza, (2011)

[6] A. Duany, E. Plater-Zyberk, J. Speck: Suburban Nation: The Rise of sprawl and the Decline of the American Dream. New York, North Point Press (2000)

[7] Preliminary Document Piano Strutturale Comunale (PSC) of Reggio Calabria, (2011)

[8] S. Ombuen, M. Ricci, O. Segnalino: I programmi complessi, Milano. Il sole 24 Ore (2000)

[9] P. Morano, F. Tajani, The transfer of development rights for the regeneration of developments sites. In: The 2nd International Conference on Civil, Architectural and Hydraulic Engineering (ICCAHE 2013). APPLIED MECHANICS AND MATERIALS, vol. 409-410, p. 971-978, Trans Teach Publications Ltd, ISSN: 1660-9336, doi: 10.4028/http.www.scientific.net/AMM.409-410.971, (2013)

[10] P. Morano: Un modello di perequazione urbanistico estimativo, Graffiti. Napoli (1998)

[11] F. Calabrò, L. Della Spina, The cultural and environmental resources for sustainable development of rural areas in economically disadvantaged contexts. Economic-appraisals issues of a model of management for the valorisation of public assets. In: 3rd International Conference on Energy, Environment and Sustainable Development (ICEESD 2013). Advanced Materials Research Vols. 869-870 (2014) pp 43-48 (C) (2014) Trans Tech Publications, Switzerland doi:10.4028/www.scientific.net/AMR.869-870.43, (2014). 
[12] F. Calabrò, L. Della Spina: The public-private partnerships in buildings regeneration: a model appraisal of the benefits and for land value capture. In: 5nd KKU International Engineering Conference 2014 (KKU-IENC 2014). ADVANCED MATERIALS RESEARCH, Vols. 931932 (2014) pp 555-559 (C) (2014) Trans Tech Publications, Switzerland doi:10.4028/www.scientific.net/AMR.931-932.555, (2014)

[13] Regione Calabria, Assessorato LL.PP, Unioncamere Calabria - Prezzario opere civili, (2012)

[14] C. Forte, B. de' Rossi: Principi di economia e di estimo. Milano. Etas (1992)

[15] A. Realfonso: Teoria e metodo dell'estimo urbano, Roma. Nis (1994)

[16] D. Lgs. n. 163/2010, art. 32 c. 2.

[17] D.P.R. 207/2011. 